\title{
Synthesis, Electrochemical, Spectrophotometric and Potentiometric Studies of Two Azo-Compounds Derived from 4-Amino-2-Methylquinoline in Ethanolic-Aqueous Buffered Solutions
}

\author{
Mona A. El-Attar, ${ }^{*, a}$ Iqbal M. Ismail ${ }^{b}$ and Mohamed M. Ghoneim ${ }^{a}$ \\ ${ }^{a}$ Analytical Chemistry Research Unit, Chemistry Department, Faculty of Science, \\ Tanta University, 31527 Tanta, Egypt \\ ${ }^{b}$ Chemistry Department, Faculty of Science, King Abdul Aziz University, \\ 21589 Jeddah, Saudi Arabia
}

\begin{abstract}
Dois compostos-azo, 2-metil-4-(5-amino-2-hidróxi-fenilazo)-quinolina e 2-metil-4-(5-amino2-hidróxi-nitrofenilazo)-quinolina, derivados da 4-amino-2-metilquinolina foram sintetizados. Suas estruturas químicas foram caracterizadas e confirmadas através de análise elementar, espectroscopia no infravermelho (IR), ressonância magnética nuclear (RMN) de ${ }^{1} \mathrm{H}$ e espectrometria de massas (MS). O comportamento eletroquímico do composto de partida (4-amino-2-metilquinolina) e dos dois azo-derivativos sintetizados foi estudado com um eletrodo de mercúrio em solução tampão universal B-R em diferentes valores de $\mathrm{pH}(2-11,5)$ contendo etanol $40 \%$ (v/v) usando polarografia dc, voltametria cíclica e coulometria com potencial controlado. Os caminhos de reação dos compostos no eletrodo foram elucidados e são discutidos. As constantes de dissociação (pKa) dos compostos examinados, constantes de estabilidade e estequiometria dos complexos formados em soluções dos compostos com alguns íons de metais de transição (Co(II), Ni(II), $\mathrm{Cu}(\mathrm{II}), \mathrm{La}(\mathrm{III})$ and $\mathrm{UO}_{2}^{2+}$ ) foram determinadas.
\end{abstract}

Two azo-compounds, 2-methyl-4-(5-amino-2-hydroxy-phenylazo)-quinoline (2) and 2-methyl4-(2-hydroxy-5-nitrophenylazo)-quinoline, derived from 4-amino-2-methylquinoline were synthesized. Their chemical structures were characterized and confirmed by means of elemental chemical analysis, infrared (IR) spectroscopy, ${ }^{1} \mathrm{H}$ nuclear magnetic resonance (NMR) and mass spectrometry (MS). The electrochemical behavior of the starting compound (4-amino2-methylquinoline) and of the two synthesized azo-derivatives was studied at the mercury electrode in the B-R universal buffer at various $\mathrm{pH}$ values (2-11.5) containing $40 \%$ (v/v) ethanol using dc-polarography, cyclic voltammetry and controlled-potential coulometry. Their electrode reaction pathways were elucidated and discussed. The dissociation constants ( $\mathrm{pKa}$ ) of the examined compounds, stability constants and stoichiometry of their complexes in solution with some transition metal ions ( $\mathrm{Co}(\mathrm{II}), \mathrm{Ni}(\mathrm{II}), \mathrm{Cu}(\mathrm{II}), \mathrm{La}(\mathrm{III})$ and $\mathrm{UO}_{2}^{2+}$ ) were determined.

Keywords: 4-amino-2-methylquinoline, azo-derivatives, voltammetry, spectrophotometry, potentiometry

\section{Introduction}

Synthetic azo-dyes are among the most explored classes of organic compounds. Azo-dyes are widely used in many practical applications such as photochromic materials, colorants, non-linear optics, sensors and indicators. ${ }^{1-12}$ The synthesis and spectral properties of several azo-dyes as well as of their transition metal complexes have been reported in the literature. ${ }^{13-17}$ The electrochemical behavior and

*e-mail: maema.2011@yahoo.com electrode reaction pathways of numerous azo-dyes in various supporting electrolytes were studied and discussed. ${ }^{18-25}$ Although the electrochemical behavior of some Schiff base compounds derived from 4-amino-2-methyquinoline has been reported, ${ }^{26}$ no studies concerning the electrochemical behavior of the latter one or its azo-derivatives are reported in the literature to date.

In the present work, two azo-derivatives from 4-amino2-methylquinoline were synthesized and characterized. Their electrochemical behavior was investigated at mercury electrodes. Besides, the dissociation constants ( $\mathrm{pKa}$ ) 
of the investigated compounds, stability constant and stoichiometry of their metal complexes in solution with some transition metal ions were determined.

\section{Experimental}

Synthesis of 2-methyl-4-(5-amino-2-hydroxyl-phenylazo)quinoline (2)

According to the general procedure for synthesis of azo-compounds reported in the literature, ${ }^{27} 0.01 \mathrm{~mol}$ of the starting compound, 4-amino-2-methylquinoline (1) (Aldrich), was converted to 4-(diazonium salt)2-methylquinoline by dissolving in a mixture consisting of $4 \mathrm{~mL}$ water and $8 \mathrm{~mL}$ of $9.8 \mathrm{~mol} \mathrm{~L}^{-1} \mathrm{HCl}$. The reaction mixture was stirred until a clear solution was obtained; cooled over crushed ice at $0-5{ }^{\circ} \mathrm{C}$, then $5 \mathrm{~mL}$ water containing $0.01 \mathrm{~mol}$ of sodium nitrite were added portion wise under gentle stirring for $30 \mathrm{~min}$ to complete the reaction. ${ }^{27}$ The resulting diazonium salt was slowly added under moderate stirring to a pre-cooled solution of $p$-aminophenol (Aldrich) $(0.01 \mathrm{~mol})$ dissolved in $30 \mathrm{~mL}$ of $10 \%(\mathrm{v} / \mathrm{v}) \mathrm{NaOH}$ aqueous solution and stirred for $30 \mathrm{~min}$, then allowed to reach room temperature. The final product was obtained as a colored azo-dye (2-methyl-4-(5-amino2-hydroxy-phenylazo)-quinoline), which was separated, filtered and several times washed with bidistilled water, dried under vacuum and recrystallized from ethanol to give brown crystals of compound (2). Yield $67 \%$; mp $98{ }^{\circ} \mathrm{C}$; anal. calcd. for $\mathrm{C}_{16} \mathrm{H}_{14} \mathrm{~N}_{4} \mathrm{O}$ (278.12 $\left.\mathrm{g} \mathrm{mol}^{-1}\right) \mathrm{C}, 69.05$; $\mathrm{H}, 5.07$; N, 20.13; found C, 69.73; H, 5.65; N, 20.52;
IR (KBr) $v_{\max } / \mathrm{cm}^{-1} 3403(\mathrm{OH}), 1650(\mathrm{~N}=\mathrm{N}), 2975\left(\mathrm{CH}_{3}\right)$; ${ }^{1} \mathrm{H}$ NMR (DMSO- $\left.d_{6}, 298 \mathrm{~K}, \mathrm{TMS}\right) \delta / \mathrm{ppm} 2.41$ (s, 3H, $\left.\mathrm{CH}_{3}\right) ; 4.23\left(\mathrm{~s}, 2 \mathrm{H}, \mathrm{NH}_{2}\right), 5.11(\mathrm{~s}, \mathrm{OH}), 7.14$ (s, pyridyl H), 6.55-7.32 (m, 3H subs. phenyl), 7.42-8.12 (m, 4H fused phenyl). The diazo-coupling reaction ${ }^{27}$ for synthesis of compound (2) is illustrated in Scheme 1.

Synthesis of 2-methyl-4-(2-hydroxy-5-nitrophenylazo)quinoline (3)

2-Methyl-4-(2-hydroxy-5-nitrophenylazo)-quinoline (3) was synthesized in a similar fashion as compound (2) but using $p$-nitrophenol (Aldrich) instead of $p$-aminophenol to give yellow crystals. Yield $64 \%$; $\mathrm{mp} 112^{\circ} \mathrm{C}$; anal. calc. for $\mathrm{C}_{16} \mathrm{H}_{12} \mathrm{~N}_{4} \mathrm{O}_{3}\left(308.09 \mathrm{~g} \mathrm{~mol}^{-1}\right) \mathrm{C}, 62.33 ; \mathrm{H}, 3.92 ; \mathrm{N}, 18.17$; found $\mathrm{C}, 62.85 ; \mathrm{H}, 4.15 ; \mathrm{N}, 18.64$; IR $(\mathrm{KBr}) \mathrm{v}_{\max } / \mathrm{cm}^{-1}$ $3327(\mathrm{OH}), 1662(\mathrm{~N}=\mathrm{N}), 2948$ (aliphatic $\mathrm{H}), 1390\left(\mathrm{NO}_{2}\right)$; ${ }^{1} \mathrm{H}$ NMR (DMSO- $d_{6}, 298 \mathrm{~K}$, TMS) $\delta / \mathrm{ppm} 2.52\left(\mathrm{~s}, 3 \mathrm{H}, \mathrm{CH}_{3}\right.$ ), 6.34 (s, pyridyl H), 7.3-7.6 (m, 3H, subs. phenyl), 7.38-7.96 $\left(\mathrm{m}, 4 \mathrm{H}\right.$, fused phenyl). The diazocoupling reaction ${ }^{27}$ for synthesis of compound (3) is illustrated in Scheme 1.

\section{Solutions}

Standard stock solutions $\left(5 \times 10^{-3} \mathrm{~mol} \mathrm{~L}^{-1}\right)$ of each of the investigated compounds $(\mathbf{1}, \mathbf{2}$ and $\mathbf{3})$ were prepared in appropriate volume of ethanol (Merck). Desired diluted solutions were prepared by accurate dilution of the standard stock solutions with ethanol. Solutions $\left(2 \times 10^{-3} \mathrm{~mol} \mathrm{~L}^{-1}\right)$ of each of the metal salts $\left(\mathrm{CoCl}_{2} \cdot 6 \mathrm{H}_{2} \mathrm{O}, \mathrm{NiCl}_{2} \cdot 6 \mathrm{H}_{2} \mathrm{O}\right.$, $\mathrm{CuCl}_{2} \cdot 2 \mathrm{H}_{2} \mathrm{O}, \mathrm{La}\left(\mathrm{NO}_{3}\right)_{3} \cdot 6 \mathrm{H}_{2} \mathrm{O}$ and $\left.\mathrm{UO}_{2}(\mathrm{Ac})_{2} \cdot 2 \mathrm{H}_{2} \mathrm{O}\right)$ were<smiles>Cc1cc(N)c2ccccc2n1</smiles>

4-Amino-2-methylquinoline (1)

4-(diazonium salt)-2-methylquinoline<smiles>Cc1cc(N=Nc2cc(N)nc3ccccc23)c2ccccc2c1N=Nc1cc([N+](=O)[O-])ccc1O</smiles>

(2)

(3)

Scheme 1. Diazo-coupling reaction for synthesis of the two azo-compounds (2 and $\mathbf{3}$ ). 
also prepared by dissolving the accurate weight of the metal salt in appropriate volumes of deionized water. Also, $0.01 \mathrm{~mol} \mathrm{~L}^{-1} \mathrm{HCl}, 1 \mathrm{~mol} \mathrm{~L}^{-1} \mathrm{KCl}$ and $0.02 \mathrm{~mol} \mathrm{~L}^{-1} \mathrm{NaOH}$ solutions were prepared in deionized water.

A set of the Britton-Robinson (B-R) universal buffer of $\mathrm{pH}$ values 2-11.5 was prepared in bidistilled water and used as a supporting electrolyte in the presence of $40 \%$ $(\mathrm{v} / \mathrm{v})$ ethanol. All chemicals used were of analytical grade (BDH or Merck) and were used without further purification.

\section{Apparatus and procedures}

\section{Physical measurements}

Elemental analysis of the synthesized azo-compounds ( 2 and 3) was carried out using Perkin Elmer 2400 elemental analyzer (Central Laboratory for Searching \& Microanalysis, Tanta University, Egypt). Their melting points were measured using a Gallenhamp apparatus and were uncorrected. Infrared (IR) spectra of the solid compounds were recorded on a Jasco FT/IR-4100-A spectrophotometer within the range $4000-400 \mathrm{~cm}^{-1}$ as $\mathrm{KBr}$ discs (Microanalytical unit, Kafr El-Sheikh University, Egypt). ${ }^{1} \mathrm{H}$ nuclear magnetic resonance (NMR) spectra were recorded on a Varian EM 390-90 NMR spectrometer (Micro Analysis Center, Cairo University, Egypt) using DMSO- $d_{6}$ (Merck) as a solvent and tetramethylsilane (TMS) as an internal standard at room temperature. The ${ }^{1} \mathrm{H}$ NMR chemical shifts $(\delta, \mathrm{ppm})$ are given relative to residual solvent peak. Mass spectral measurements of the synthesized compounds were made on a DI Analysis Shimadzu Qp-2010 Plus (Micro Analysis Center, Cairo University, Egypt).

\section{Electrochemical measurements}

A Sargent-Welch Polarograph model 4001 (Fisher, USA) was used in the dc-polarographic measurements. The electrochemical cell used was as described by Meites. ${ }^{28}$ Characteristics of the capillary used as dropping mercury electrode (DME) were $m$ of $1.2 \mathrm{mg} \mathrm{s}^{-1}$ and $t$ of $3.5 \mathrm{~s}$ in a solution of $0.1 \mathrm{~mol} \mathrm{~L}^{-1} \mathrm{KCl}$ at open circuit and a mercury height of $60 \mathrm{~cm}$. A saturated calomel electrode (SCE) was used as a reference electrode.

A computer-controlled Potentiostat/Galvanostat model 273A-PAR (Princeton Applied Research, Oak Ridge, TN, USA) and the electrode assembly model 303A-PAR with the software package 270/250-PAR were used in cyclic voltammetric measurements. A micro-electrochemical cell incorporated of a three-electrode configuration system comprising of a hanging mercury drop electrode (HMDE) as a working electrode (surface area of $0.026 \mathrm{~cm}^{2}$ ), an $\mathrm{Ag} / \mathrm{AgCl} / \mathrm{KCl}_{\mathrm{s}}$ reference electrode and a platinum wire auxiliary electrode was used.
Mercury, gold, platinum and various carbonaceous materials are the most frequently used working electrodes in electrochemical studies. The use of mercury electrodes has been recently discouraged mainly due to environmental reasons ( $\mathrm{Hg}$ is a toxic element). Mercury has a high hydrogen overvoltage that greatly extends the cathodic potential window up to about $-2 \mathrm{~V}$ in aqueous solution. Due to its wide cathodic potential window, mercury was frequently used as working electrodes (e.g., DME and HMDE) for electroreduction of substances of very negative reduction potential in aqueous electrolyte. Besides, it was successfully used as a working electrode for substance that strongly adsorbs onto the surface of solid electrodes. The mercury electrode is far superior to other solid electrodes in this regard since great care must be exercised with such solid electrodes to ensure that their surfaces are not changed by the electrochemical reactions. On the other side, mercury electrode (e.g., DME) also possesses a highly reproducible, readily renewable and smooth surface.

The appropriate concentration of each of the examined compounds in $10 \mathrm{~mL}$ B-R universal buffer in the presence of $40 \%$ (v/v) ethanol was introduced into the electrochemical cell, and then deoxygenated with pure nitrogen gas for about $10 \mathrm{~min}$ and for $30 \mathrm{~s}$ in each successive cycle, while a stream of nitrogen gas was kept over the solution during the measurements.

A potentiostat/galvanostat model 173-PAR incorporated with a digital coulometer model 179-PAR (Princeton Applied Research, Oak Ridge, TN, USA) was used for the controlled-potential coulometric measurements at a mercury pool cathode. A micro-coulometric cell incorporated with a Pt wire sealed through the cell bottom for contact with the mercury pool as a working electrode, a reference SCE and a platinum gauze as a counter electrode was used.

Controlled-potential electrolysis of solution $\left(2.5 \times 10^{-4} \mathrm{~mol} \mathrm{~L}^{-1}\right)$ of each of the investigated compounds was performed in the B-R universal buffer of various $\mathrm{pH}$ values containing $40 \%(\mathrm{v} / \mathrm{v})$ ethanol to determine the total number of electrons consumed in the overall electrode reaction. The applied potential was adjusted to be around the half-wave $\left(\mathrm{E}_{1 / 2}\right)$ potential $( \pm 0.1 \mathrm{~V} v s$. SCE) or at the plateau of the limiting current of each of the recorded reduction waves. Prior to measurements, the electrolyzed solutions were deoxygenated by bubbling with pure nitrogen gas. During the measurements, a constant stream of nitrogen gas was passed over the surface of the electrolysis solution. The total charge Q (Coulombs) consumed during the complete electrolysis of the reactant was calculated by electronically integrating the current, after subtracting the background current. The number 
of electrons (n) transferred per electrolyzed molecule at various $\mathrm{pH}$ values was estimated using Faraday's equation: $\mathrm{N}=\mathrm{Q} / \mathrm{nF}$ where $\mathrm{N}$ is the number of moles of substance being electrolyzed and $\mathrm{F}$ the Faraday's constant $\left(96,485 \mathrm{C} \mathrm{mol}^{-1}\right)$.

A pH-meter model HI8014 (Hanna Instruments, Italy) accurate to $\pm 0.01 \mathrm{pH}$ units was used for the $\mathrm{pH}$ measurements. A Mettler balance (Toledo-AB104, Greifensee, Switzerland) was used for weighing the solid materials. Deionized water was obtained from a Purite-Still Plus deionizer connected to an AquaMatic double-distillation water system (Hamilton Laboratory Glass Ltd., Kent, UK).

\section{Spectrophotometric measurements}

UV-Visible absorbance spectra of the examined compounds were recorded within the wavelength range 200-800 nm at room temperature using a Shimadzu UV-Vis spectrophotometer model 160A (Kyoto, Japan) with a quartz spectrometric cell ( $1 \mathrm{~cm}$ bath length). The absorbance spectra were scanned for the following mixtures: $5 \mathrm{~mL}$ of B-R universal buffer $+4.8 \mathrm{~mL} \mathrm{H}_{2} \mathrm{O}+0.2 \mathrm{~mL} \mathrm{EtOH}$ as blank, while for the sample $5 \mathrm{~mL}$ of $\mathrm{B}-\mathrm{R}$ universal buffer + $4.8 \mathrm{~mL} \mathrm{H}_{2} \mathrm{O}+0.2 \mathrm{~mL}$ of $2.5 \times 10^{-3} \mathrm{~mol} \mathrm{~L}^{-1}$ azo-compound dissolved in ethanol.

\section{Potentiometric measurements}

Potentiometric measurements were performed using a pH-meter model HI8014 (Hanna Instruments, Italy) accurate to $\pm 0.01 \mathrm{pH}$ units. The electrode was standardized before and checked after each titration with standard buffer solution (Fisher, New Jersey, USA). A standard $0.02 \mathrm{~mol} \mathrm{~L}^{-1} \mathrm{NaOH}$ aqueous-ethanolic solution ( $40 \% \mathrm{v} / \mathrm{v}$ ethanol) was added from a $5 \mathrm{~mL}$ total volume micro burette accurate to $0.01 \mathrm{~mL}$ and the contents of the titration vessel were stirred using a magnetic stirrer (Sargent-Welch, USA). All titration measurements were carried out at $298 \mathrm{~K}$ by circulating water from an Ultra-thermostat (JULABO F10, Seelbach, Germany) through the annular space of a double-walled Pyrex titration cell of $50 \mathrm{~mL}$ capacity. Each of the following mixtures was prepared and potentiometrically titrated against a standard $0.02 \mathrm{~mol} \mathrm{~L}-1 \mathrm{NaOH}$ aqueous-ethanolic solution ( $40 \% \mathrm{v} / \mathrm{v}$ ethanol) at $298 \mathrm{~K}$. The volume was made up to $50 \mathrm{~mL}$ using bidistilled water before the titration, keeping ethanol content at $40 \%(\mathrm{v} / \mathrm{v})$ in all titrated solution mixtures: (i) $5 \mathrm{~mL}$ of $0.01 \mathrm{~mol} \mathrm{~L}^{-1} \mathrm{HCl}+5 \mathrm{~mL}$ of $1 \mathrm{~mol} \mathrm{~L}^{-1}$ $\mathrm{KCl}+20 \mathrm{~mL} \mathrm{EtOH}+20 \mathrm{~mL} \mathrm{H}_{2} \mathrm{O}$; (ii) $5 \mathrm{~mL}$ of $0.01 \mathrm{~mol} \mathrm{~L}^{-1}$ $\mathrm{HCl}+5 \mathrm{~mL}$ of $1 \mathrm{~mol} \mathrm{~L}^{-1} \mathrm{KCl}+5 \mathrm{~mL}$ of $5 \times 10^{-3} \mathrm{~mol} \mathrm{~L}^{-1}$ azo compound $+15 \mathrm{~mL} \mathrm{EtOH}+20 \mathrm{~mL} \mathrm{H}_{2} \mathrm{O}$; and (iii) $5 \mathrm{~mL}$ of $0.01 \mathrm{~mol} \mathrm{~L}^{-1} \mathrm{HCl}+5 \mathrm{~mL}$ of $1 \mathrm{~mol} \mathrm{~L}^{-1} \mathrm{KCl}+5 \mathrm{~mL}$ of $5 \times 10^{-3} \mathrm{~mol} \mathrm{~L}^{-1}$ azo-compound $+5 \mathrm{~mL}$ of $2 \times 10^{-3} \mathrm{~mol} \mathrm{~L}^{-1}$ metal ion (Co(II), $\mathrm{Ni}(\mathrm{II}), \mathrm{Cu}(\mathrm{II}), \mathrm{La}(\mathrm{III})$ or $\left.\mathrm{UO}_{2}^{2+}\right)+15 \mathrm{~mL}$ $\mathrm{EtOH}+15 \mathrm{~mL} \mathrm{H}_{2} \mathrm{O}$.

A constructed QuickBasic language-PC program was used in computing the data resulted from potentiometric measurements to estimate the dissociation constants (pKa) of examined azo-derivatives and the stability constants and stoichiometry of their metal-complexes in solution.

\section{Results and Discussion}

Characterization of the synthesized azo-derivatives ( 2 and $\mathbf{3}$ )

As described in the Experimental section, the results provided by the different techniques are in good agreement with the chemical formulae proposed for the synthesized compounds $\mathbf{2}$ and $\mathbf{3}$. IR spectra of compounds $\mathbf{2}$ and $\mathbf{3}$ are shown in the Supplementary Information (SI) section (Figure S1). In this section, the mass spectra of compounds 2 and 3 (Figure S2) and their fragmentation patterns (Figures S3 and S4) are presented. The IR spectral bands of compounds 2 and $\mathbf{3}$ at $1650-1662 \mathrm{~cm}^{-1}$ were assigned for the $\mathrm{N}=\mathrm{N}$ group. The stretching vibration bands, $\mathrm{v}(\mathrm{OH})$, of the hydroxyl group were found at $3327-3403 \mathrm{~cm}^{-1}$. The bands at $2948-2975 \mathrm{~cm}^{-1}$ characterize the $v\left(\mathrm{CH}_{3}\right)$ stretching vibration. In compound $\mathbf{3}$, the band at $1390 \mathrm{~cm}^{-1}$ characterizes the nitro group (Figure $\mathrm{S} 1$ in the SI section).

The ${ }^{1} \mathrm{H}$ NMR spectrum of compound (2) exhibited singlet for 3 protons of $\left(\mathrm{CH}_{3}\right)$ group at $\delta 2.41$, singlet for $\left(\mathrm{NH}_{2}\right)$ at $\delta 4.23$, singlet for $(\mathrm{OH})$ at $\delta 5.11$, singlet for pyridyl proton attached to $\mathrm{C} 3$ at $\delta 7.14$, multiplet for 3 aromatic protons at $\delta 6.55-7.32$ and multiplet for 4 protons of fused phenyl at $\delta 7.42-8.12$.

For compound (3), the ${ }^{1} \mathrm{H}$ NMR spectrum exhibited a singlet for 3 protons of $\left(\mathrm{CH}_{3}\right)$ group at $\delta 2.52$, singlet for pyridyl proton attached to $\mathrm{C} 3$ at $\delta 6.34$, multiplet for 3 aromatic protons of substituted phenyl at $\delta$ 7.3-7.6 and multiplet for 4 protons of fused phenyl at $\delta$ 7.38-7.96.

The mass spectral assignment of compound (2) showed a strong molecular ion peak $\left[\mathrm{M}^{+}\right]$at $\mathrm{m} / z(278,48 \%)$ (Figure S2 in the SI section). Decomposition of this ion may take place through two pathways. In the first path, the compound loses $\mathrm{CH}_{3}$ radical forming ion at $m / z(263,14 \%)$, then it loses three $\mathrm{H}$ radicals, producing ion with a base peak at $m / z(260,100 \%)$. The second path, $\left[\mathrm{M}^{+}\right]$lose $\mathrm{C}_{6} \mathrm{H}_{6} \mathrm{ON}$ radical, forming ion at $m / z(170,56 \%)$, this decomposition step was confirmed by the appearance of peak at $\mathrm{m} / \mathrm{z}(108$, $74 \%$ ), characterized for $\mathrm{C}_{6} \mathrm{H}_{6} \mathrm{ON}$ radical. The fragment ion at $m / z(170,56 \%)$ may lose nitrogen gas followed by five $\mathrm{H}$ radicals forming ions at $\mathrm{m} / \mathrm{z}(142,34 \%)$ and (137, $1 \%$ ), respectively (Figure S3 in the SI section). The mass spectral assignment of compound (3) showed an intense 
molecular ion peak [M] ${ }^{+}$at $\mathrm{m} / \mathrm{z}(308,100 \%)$ corresponding to the formula $\mathrm{C}_{16} \mathrm{H}_{12} \mathrm{O}_{3} \mathrm{~N}_{4}$ (Figure $\mathrm{S} 2$ in the SI section). The $\left[\mathrm{M}^{+}\right]$may decompose through several fragmentation paths. In the first, the molecule loses $\mathrm{C}_{10} \mathrm{H}_{8} \mathrm{~N}_{3}$ moiety, forming ion with a peak at $m / z, 138,37 \%$. The decomposed ion $\left(\mathrm{C}_{10} \mathrm{H}_{8} \mathrm{~N}_{3}\right)$ with peak at $\mathrm{m} / \mathrm{z}(170,43 \%)$ may lose $\mathrm{CH}_{3}$ group and $\mathrm{N}_{2}$ gas forming an ion at $m / z 127$, which may take hydrogen radical, forming ion with peak at $m / z$ (128, $72 \%)$. In the second path, $\left[\mathrm{M}^{+}\right]$lose nitro group forming ion with peak at $m / z(262,59 \%)$. The third path, $\left[\mathrm{M}^{+}\right]$may lose $\mathrm{CH}_{3}$ group and hydroxyl radical, forming ion at $\mathrm{m} / \mathrm{z}$ 276 , in which it takes three hydrogen radicals, forming ion with peak at $m / z(279,64 \%)$ (Figure S4 in the SI section).

\section{Electrochemical studies}

DC-polarographic and cyclic voltammetric behaviors of 4-amino-2-methylquinoline (1) and its two synthesized azo-derivatives ( 2 and 3 ) of $2.5 \times 10^{-4}$ and $1 \times 10^{-4} \mathrm{~mol} \mathrm{~L}^{-1}$, respectively, were studied in the B-R universal buffer of various $\mathrm{pH}$ values (2-11.5) containing $40 \%(\mathrm{v} / \mathrm{v})$ ethanol. The voltammograms of 4-amino-2-methylquinoline (1) exhibited a single 2-electron irreversible step in solutions of $\mathrm{pH}$ values (7-11) at $\mathrm{E}_{1 / 2}$ ca. -1.52 to $-1.71 \mathrm{~V}$ (Figure 1, curves $\mathrm{a}, \mathrm{b}$ and $\mathrm{c}$, and Figure 2, curves a and b). For 2-methyl-4-(5-amino-2-hydroxy-phenylazo)-quinoline (2), the voltammograms exhibited two main 2-electron irreversible cathodic steps $\left(\mathrm{E}_{1 / 2} \mathrm{ca}\right.$. -0.18 to $-0.71 \mathrm{~V}$ and -0.75 to $-1.26 \mathrm{~V}$ ) for the $1^{\text {st }}$ and $2^{\text {nd }}$ waves, respectively, over the entire $\mathrm{pH}$ range (2-11.4) (Figure 1, curves d, $\mathrm{e}$ and $\mathrm{f}$, and Figure 2, curves $\mathrm{c}$ and d). Besides, an additional irreversible cathodic step was obtained at more negative potentials $\left(\mathrm{E}_{1 / 2} \mathrm{ca}\right.$. -1.1 to $\left.-1.43 \mathrm{~V}\right)$ in solutions of $\mathrm{pH}$ values 4-9 (Figure 1, curve e, and Figure 2, curve c); its limiting or peak current was gradually decreased upon the increase of $\mathrm{pH}$ of the medium until complete disappearance at $\mathrm{pH}$ higher than 9 (Figure 1, curve f, and Figure 2, curve d).

For 2-methyl-4-(2-hydroxy-5-nitrophenylazo]quinoline (3), the voltammograms showed a main 8-electron irreversible cathodic step ( $\mathrm{E}_{1 / 2}$ ca. -0.34 to $-0.97 \mathrm{~V}$ ) in solutions of $\mathrm{pH}$ values lower than 10 (Figure 1, $1^{\text {st }}$ wave, curves g, h and i, and Figure 2, curve e), which splits into two steps in solutions of $\mathrm{pH}$ values higher than 10 (Figure 1, curve $\mathrm{j}$, and Figure 2, curve g). An additional irreversible cathodic step was also obtained at more negative potentials $\left(\mathrm{E}_{1 / 2}\right.$ ca. $-1.4 \mathrm{~V}$ ) in solutions of $\mathrm{pH}$ values 4-9 (Figure 1, curves $h$ and i, and Figure 2, curve f), its limiting current gradually decreased upon the increase of $\mathrm{pH}$ of the medium until complete disappearance at $\mathrm{pH}$ values higher than 9 (Figure 1, curve j, and Figure 2, curve g). The half-wave potentials $\left(\mathrm{E}_{1 / 2}\right)$ or the peak potentials $\left(\mathrm{E}_{\mathrm{p}}\right)$ shifted to more

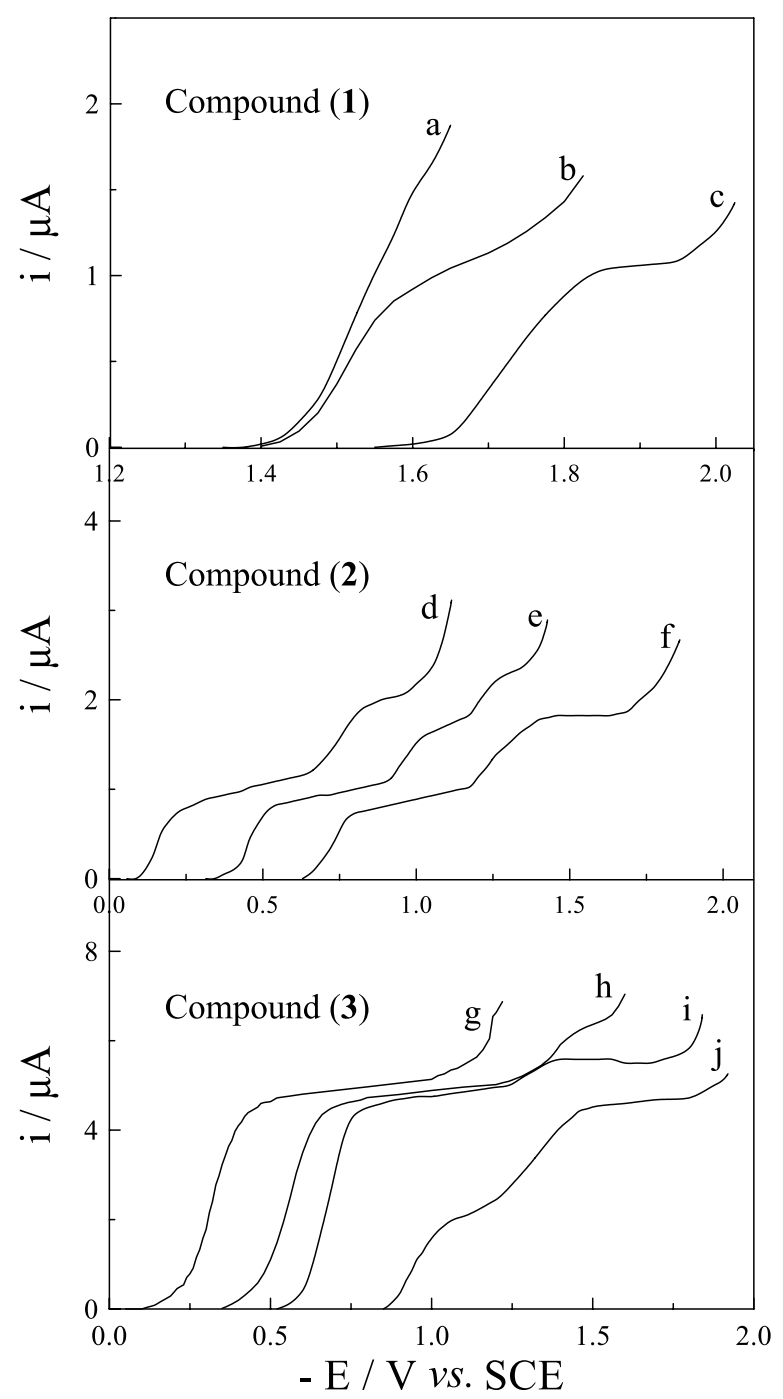

Figure 1. DC-polarograms of the examined compounds $\left(2.5 \times 10^{-4} \mathrm{~mol} \mathrm{~L}^{-1}\right)$ in the B-R universal buffer of various $\mathrm{pH}$ values containing $40 \%(\mathrm{v} / \mathrm{v})$ ethanol, compound (1): (a) 6.2, (b) 7.2 and (c) 11.0, compound (2): (d) 2.0, (e) 7.1 and (f) 11.4, and compound (3): (g) 2.4, (h) 6.1, (i) 7.7 and (j) 11.4.

negative values on the increase of either the $\mathrm{pH}$ of the medium and the scan rate $v$, indicating the involvement of proton in the electrode processes ${ }^{29}$ and the irreversible nature of the reduction processes, ${ }^{29,30}$ respectively.

The reduction waves of the examined compounds at the DME were analyzed using the fundamental equation for the irreversible polarographic waves: $:^{28}$

$\mathrm{E}_{\text {d.e. }}=\mathrm{E}_{1 / 2}-\left(0.0591 / \alpha \mathrm{n}_{\mathrm{a}}\right) \log \left(\mathrm{i} /\left(\mathrm{i}_{1}-\mathrm{i}\right)\right)$

Plots of $\mathrm{E}_{\text {d.e }} v s . \log \left(\mathrm{i} /\left(\mathrm{i}_{1}-\mathrm{i}\right)\right)$ for the polarographic waves of investigated compounds at various $\mathrm{pH}$ values were straight lines with slope values $S_{1}\left(S_{1}, m V=59.1 / \alpha n_{a}\right)^{28}$ reported in Table 1. Values of $\alpha \mathrm{n}_{\mathrm{a}}$ ( $\alpha$ is the symmetry transfer coefficient and $n_{a}$ is the number of electrons involved in the rate-determining step) at various $\mathrm{pH}$ values 
were determined from slope $\mathrm{S}_{1}$ (Table 1). Also the $\mathrm{E}_{1 / 2} v s . \mathrm{pH}$ plots for the polarographic waves (of $\mathrm{pH}$-dependent

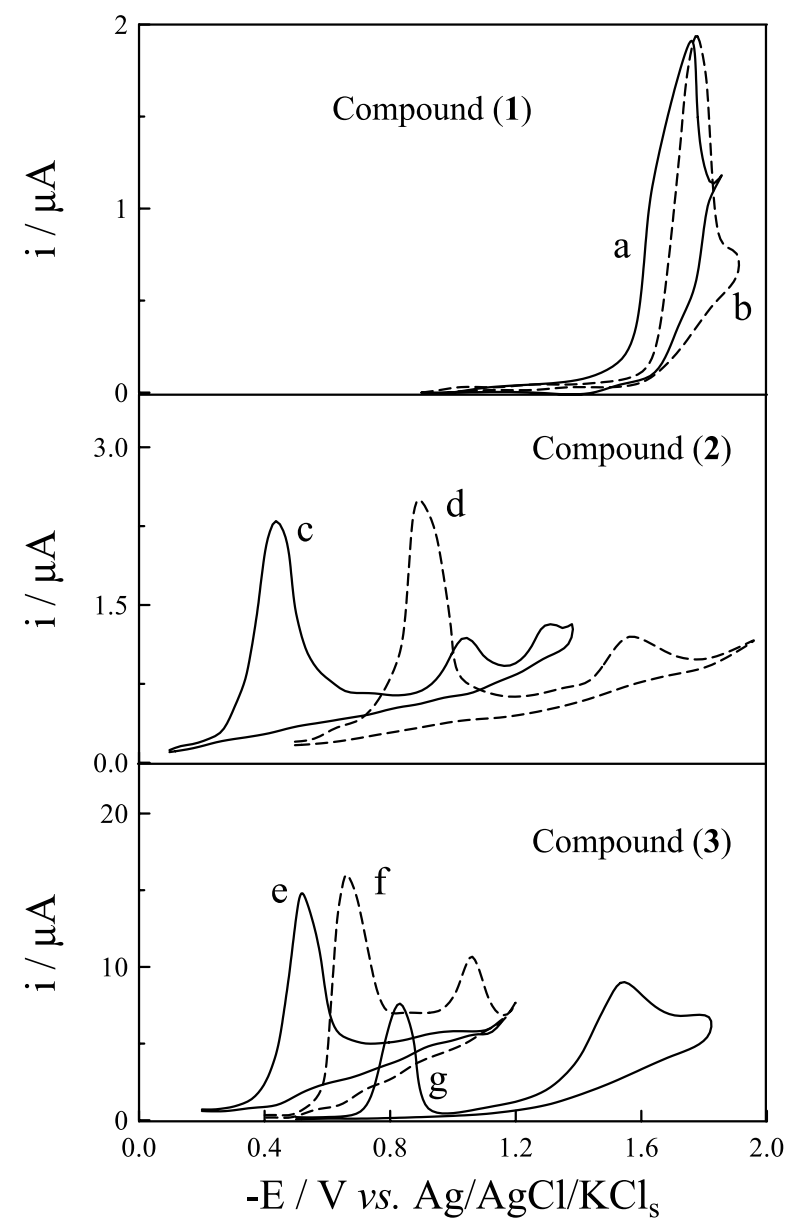

Figure 2. Cyclic voltammograms of the examined compounds $\left(1 \times 10^{-4} \mathrm{~mol} \mathrm{~L}^{-1}\right)$ in the B-R universal buffer of various $\mathrm{pH}$ values containing 40\% (v/v) ethanol, compound (1): (a) 7.4 and (b) 9.2, compound (2): (c) 4.1 and (d) 11.2, and compound (3): (e) 3.3, (f) 7.4 and (g) 11.1 ; scan rate $500 \mathrm{mV} \mathrm{s}^{-1}$.
$\mathrm{E}_{1 / 2}$ ) of the examined compounds were straight lines with slope values $S_{2}$ reported in Table 1. The number of protons (p) participating in the rate-determining step of the reduction process of the electro-active centers of the investigated compounds was determined by applying the relationship: $:^{29,31}$

$$
\begin{aligned}
& \delta \mathrm{E}_{1 / 2} / \delta \mathrm{pH}=\mathrm{S}_{2} \mathrm{mV}=\left(59.1 / \alpha \mathrm{n}_{\mathrm{a}}\right) \mathrm{p} \\
& \mathrm{p}=\mathrm{S}_{2}\left(\alpha \mathrm{n}_{\mathrm{a}} / 59.1\right)=\mathrm{S}_{2} / \mathrm{S}_{1}
\end{aligned}
$$

The data reported in Table 1 indicated that the ratedetermining step of the reduction processes involved the consumption of one proton (i.e., $\mathrm{p}=1$ ) over the entire $\mathrm{pH}$ range. The ratio $\left(\mathrm{p} / \mathrm{n}_{\mathrm{a}}\right)$ may have the value 1 (when value of $\mathrm{p}$ and $\mathrm{n}_{\mathrm{a}}$ are equal) or 0.5 (when value of $\mathrm{n}_{\mathrm{a}}$ is double that of $\mathrm{p}$ ). The most probable values obtained for $\alpha$-parameter (0.40-0.55) indicated that the ratio $\left(\mathrm{p} / \mathrm{n}_{\mathrm{a}}\right)$ equals 0.5 , which suggested that the number of electrons $n_{a}$ involved in the rate-determining step of each of the electro-active centers should be double that of the involved protons (p), i.e., $\mathrm{n}_{\mathrm{a}}=2$ and $\mathrm{p}=1$.

On the other side, linear $\mathrm{E}_{\mathrm{p}}-\mathrm{pH}$ plots of slope values $(58-60 \mathrm{mV})$ at scan rate of $200 \mathrm{mV} \mathrm{s}^{-1}$ for the examined compounds were obtained. From slope values (13-15 mV) of the obtained linear plots of Ep versus $\ln \mathrm{v}$ (slope, $\left.\mathrm{mV}=12.85 / \alpha n_{a}\right),{ }^{32}$ values of $\alpha n_{a}(0.99-0.86)$ and $\alpha(0.43-0.49)$ were also estimated at na $=2$, confirming again the irreversible nature 32 of the electrode processes of the examined compounds. Moreover, values of $\alpha n_{a}$ and $\alpha$ were also determined at various $\mathrm{pH}$ values using the equation: $\mathrm{E}_{\mathrm{p}}-\mathrm{E}_{\mathrm{p} / 2}=0.048 / \alpha \mathrm{n}_{\mathrm{a}} \mathrm{V}$, where $\left(\mathrm{E}_{\mathrm{p}}-\mathrm{E}_{\mathrm{p} / 2}\right)$ is the difference between cathodic peak potential $\mathrm{E}_{\mathrm{p}}$ and the half-peak $\mathrm{E}_{\mathrm{p} / 2}$ at half-height of peak current as a function

\begin{tabular}{|c|c|c|c|c|}
\hline $\mathrm{pH}$ range & $\mathrm{S}_{1} / \mathrm{mV}$ & $\alpha \mathrm{n}_{\mathrm{a}}$ & $\mathrm{S}_{2} / \mathrm{mV}$ & $\mathrm{p}\left(\mathrm{S}_{2} / \mathrm{S}_{1}\right)$ \\
\hline \multicolumn{5}{|c|}{ Compound (1) - reduction of quinoline moiety in a single step at various $\mathrm{pH}$ values: } \\
\hline $7.0-11.0$ & $64.5-66.7$ & $0.91-0.88$ & 53 & $\begin{array}{c}0.82-0.80 \\
\text { p ca. } 1\end{array}$ \\
\hline
\end{tabular}

Table 1. Dc-polarographic data for the investigated compounds in ethanolic-aqueous B-R universal buffer solutions containing $40 \%\left(\mathrm{v} / \mathrm{v}\right.$ ) ethanol at $25^{\circ} \mathrm{C}$

\begin{tabular}{|c|c|c|c|c|}
\hline 2.0-11.4 (a) & 68.9-69.0 & 0.86 & 56.5 & $\begin{array}{c}0.82 \\
\text { p ca. } 1\end{array}$ \\
\hline $2.0-11.4$ (b) & $66.5-70.0$ & $0.89-0.84$ & 59.3 & $\begin{array}{c}0.89-0.85 \\
\text { p ca. } 1\end{array}$ \\
\hline $4.0-9.0$ (c) & $64.4-70.3$ & $0.92-0.84$ & 74.9 & $\begin{array}{c}1.16-1.07 \\
\text { p ca. } 1\end{array}$ \\
\hline
\end{tabular}

Compound (2) - reduction of $\mathrm{N}=\mathrm{N}$ group in two steps (a) and (b), and reduction of quinoline moiety in a single step (c) at various $\mathrm{pH}$ values:

Compound (3) - reduction of both $\mathrm{N}=\mathrm{N}$ azo and $\mathrm{NO}_{2}$ groups in a single step:
2.4-11.4
78.5-83.4
0.75-0.71 
of scan rate $v$. The obtained $\alpha \mathrm{n}_{\mathrm{a}}$ values were found to equal (0.96-1.06) and consequently values of the symmetry transfer coefficient $(\alpha)$ over the $\mathrm{pH}$ range were found to equal (0.48-0.53) at $n_{a}$ equals 2 . This provided additional support of the irreversible nature ${ }^{32}$ of the electrode processes of the examined compounds.

\section{Controlled-potential electrolysis and TLC studies}

As shown in Table 2, the total number of electrons (n) transferred per molecule in the reduction process at various $\mathrm{pH}$ values for $2.5 \times 10^{-4} \mathrm{~mol} \mathrm{~L}^{-1}$ solution of each of the examined compounds $(\mathbf{1}, \mathbf{2}$ and $\mathbf{3}$ ) were determined by means of controlled-potential electrolysis as discussed in the Experimental section.

Table 2. Results of controlled-potential coulometry measurements for the examined compounds

\begin{tabular}{lccccc}
\hline \multirow{2}{*}{ Compound } & \multirow{2}{*}{ pH } & \multicolumn{5}{c}{ Number of electrons (n) transferred/molecule } \\
\cline { 3 - 6 } & & $1^{\text {st }}$ wave & $2^{\text {nd }}$ wave & $3^{\text {rd }}$ wave & Total \\
\hline $\mathbf{1}$ & 8.0 & 2 & - & - & 2 \\
$\mathbf{2}$ & 11.0 & 2 & - & - & 2 \\
& 2.8 & 2 & 2 & - & 4 \\
& 6.5 & 2 & 2 & 2 & 6 \\
$\mathbf{3}$ & 11.0 & 2 & 2 & - & 4 \\
& 2.4 & 8 & - & - & 8 \\
& 6.1 & 8 & 2 & - & 10 \\
& 11.0 & 4 & 4 & - & 8 \\
\hline
\end{tabular}

Thin layer chromatographic (TLC) experiments were carried out for monitoring the products of complete electrolysis of the solution of each of the investigated azo-compounds ( 2 and $\mathbf{3}$ ) using benzene/acetone (70:30 $\mathrm{v} / \mathrm{v}$ ) as eluent. This was performed by concentration of the completely electrolyzed solution of the each of examined azo-compounds, and then followed by extraction of the buffer ingredient with ether. The TLC-experiments showed two clear spots compared to a single spot for the starting compound (1), indicating that two products were formed due to the reduction cleavage of the $-\mathrm{N}=\mathrm{N}-$ double bond. The two products were suggested to be the corresponding primary aromatic amines. The presence of the latter one was confirmed by carrying out diazo-coupling reaction ${ }^{27,33}$ on the completely electrolyzed solutions of each of the investigated azo-compounds. Recovery of the characteristic colored azo-dye $\mathrm{e}^{27,33}$ in solution confirmed the presence of aromatic amines in the completely electrolyzed solution as a result of the reduction cleavage of $-\mathrm{N}=\mathrm{N}-$ center in each of the examined compounds ( $\mathbf{2}$ and $\mathbf{3}$ ), which confirmed our suggested reduction mechanisms of the investigated compounds.
On the other hand, the UV-Vis absorbance spectra of solutions $\left(1 \times 10^{-4} \mathrm{~mol} \mathrm{~L}^{-1}\right)$ of the investigated azo-derivatives in ethanolic-aqueous B-R universal buffer (e.g., $\mathrm{pH}$ 7) before controlled potential electrolysis showed a characteristic band at $\lambda_{\max } 400 \mathrm{~nm}$ due to the $\mathrm{n}-\pi^{*}$ transition of $-\mathrm{N}=\mathrm{N}-$ group (e.g., Figure 3; spectrum (a) for compound 3). This band disappeared completely after controlled-potential electrolysis of the examined solutions (e.g., Figure 3; spectrum (b) for compound (3)). It is important to notice that the spectra of solutions of both derivatives (2) and (3) after controlled-potential electrolysis resemble that of the starting compound (1) (Figure 3; spectrum c). This behavior confirmed the cleavage of the $-\mathrm{N}=\mathrm{N}-$ bond in both derivatives by controlled-potential electrolysis.

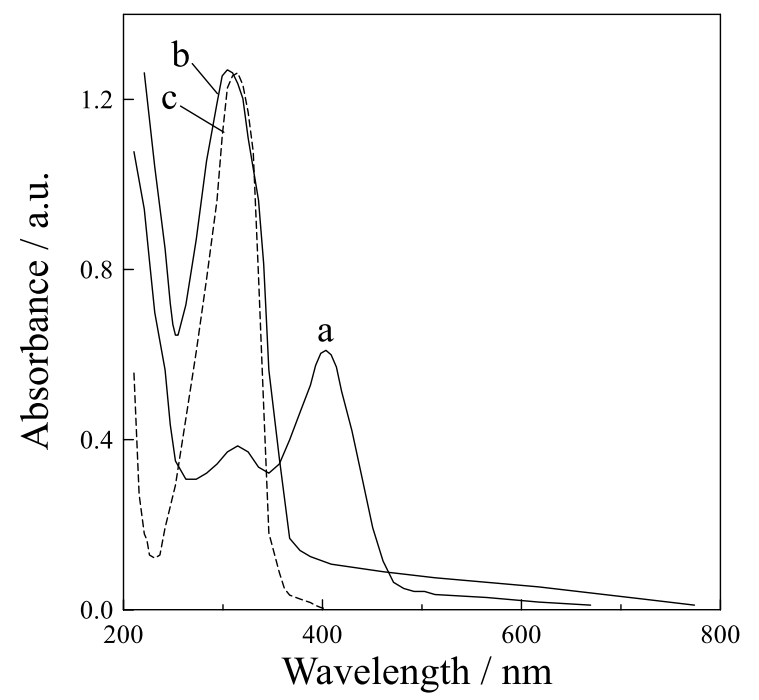

Figure 3. UV-Vis spectra of the azo-compound $(3)\left(1 \times 10^{-4} \mathrm{~mol} \mathrm{~L}^{-1}\right)$ in ethanolic-aqueous B-R universal buffer solution of $\mathrm{pH} 7$ : (a) before electrolysis and (b) after complete electrolysis at controlled-potential, compared to that of $1 \times 10^{-4} \mathrm{~mol} \mathrm{~L}^{-1}$ solution of the starting compound (1) (c).

\section{Electrode reaction pathways}

\section{Electrode reaction of compound (1)}

4-Amino-2-methylquinoline (1) was reduced at the mercury electrode in buffered solutions of $\mathrm{pH}$ values 7-11 in a single 2-electron irreversible step which is assigned to the reduction-saturation of the $-\mathrm{C}=\mathrm{N}-$ double bond of its quinoline moiety, ${ }^{34}$ as illustrated in Scheme 2.

\section{Electrode reaction of the azo-derivative (2)}

The synthesized 2-methyl-4-(5-amino-2-hydroxyphenylazo)-quinoline (2) was reduced at the mercury electrode in buffered solution of $\mathrm{pH}$ 2-11.5 in two 2-electron steps $\left(1^{\text {st }}\right.$ and $2^{\text {nd }}$ steps), which were attributed to the reduction of the $-\mathrm{N}=\mathrm{N}-$ double bond to the amine stage as illustrated in Scheme 3. The $3^{\text {rd }}$ reduction step that appeared 
<smiles>Cc1cc(N)c2ccccc2n1</smiles>

Compound (1)

(i)
Scheme 2. Electrode reaction pathway of the parent compound (1).

First step:<smiles>Cc1cc(N=Nc2cc(N)ccc2O)c2ccccc2n1</smiles>

(ii)

Second step:

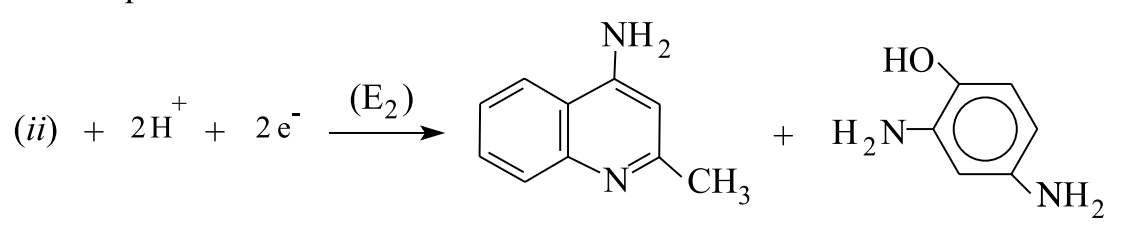

$$
\mathrm{E}_{1} \neq \mathrm{E}_{2}
$$

(Both products are primary aromatic amines)

Scheme 3. Electrode reaction pathway of the azo-derivative (2).

at more negative potential in solutions of $\mathrm{pH}$ values 4-9 is due to reduction of the $-\mathrm{C}=\mathrm{N}-$ double bond of the quinoline moiety, ${ }^{34}$ as illustrated in Scheme 2 of the electrode reaction of the starting compound (1).

\section{Electrode reaction of azo-derivative (3)}

The synthesized 2-methyl-4-(2-hydroxy5 -nitrophenylazo)-quinoline (3) was also reduced at the mercury electrode in buffered solution of $\mathrm{pH}$ values 2-10 in a single 8-electron step, which is attributed to reduction of either the $-\mathrm{N}=\mathrm{N}-$ double bond to the amine stage and the $-\mathrm{NO}_{2}$ group to the hydroxylamine stage, via the consumption of four electrons for each centre, ${ }^{24,35}$ (Scheme 4 , reaction 4). At $\mathrm{pH}$ values higher than 10 , this reduction step splits into two steps. The $1^{\text {st }}$ and $2^{\text {nd }}$ steps were attributed to the reduction-cleavage of the $-\mathrm{N}=\mathrm{N}-$ double bond to the amine stage and reduction of the $\mathrm{NO}_{2}$ group to the hydroxylamine stage, ${ }^{35}$ respectively, via the consumption of four electrons for each center (Scheme 4, reactions 5 and 6, respectively).
The reduction step that appeared at more negative potential in solutions of $\mathrm{pH}$ values 4-9 is due to reduction of the $-\mathrm{C}=\mathrm{N}-$ double bond of the quinoline moiety ${ }^{34}$ as illustrated in Scheme 2 of the electrode reaction of the starting compound (1).

\section{Spectrophotometric studies}

UV-Vis absorption spectra of $5 \times 10^{-5} \mathrm{~mol} \mathrm{~L}^{-1}$ of each of compounds (2) and (3) were recorded in the B-R universal buffer of various $\mathrm{pH}$ values (2-12) within the wavelength range 200-800 nm. Compound 2 showed two absorption bands at $\lambda_{\max } 438$ and $480 \mathrm{~nm}\left(\mathrm{n}-\pi^{*}\right)$, with an isosbestic point at $\lambda_{\max } 462 \mathrm{~nm}$ (Figure 4). While compound 3 showed two absorption bands at $\lambda_{\max } 315$ and $400 \mathrm{~nm}\left(\mathrm{n}-\pi^{*}\right)$, with an isosbestic point at $\lambda_{\max } 345 \mathrm{~nm}$ (Figure 4).

The first band may be attributed to the non-ionized form, whereas the second one that develops as the $\mathrm{pH}$ increases is due to the ionized species of each of the examined 
Single step (pH 2-10):<smiles></smiles>

Compound (3)

(Both products are primary aromtic amines)

First step $(\mathrm{pH}>10)$ :

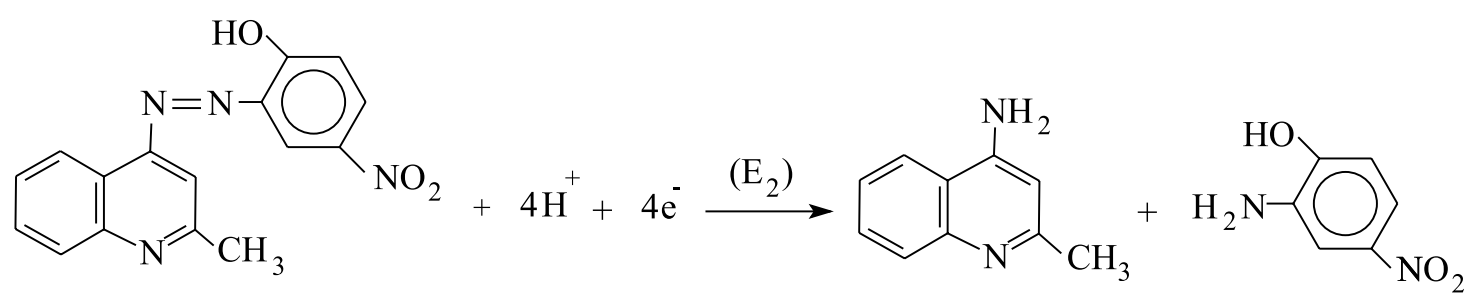

(Both products are primary aromtic amines)

Second step $(\mathrm{pH}>10)$ :<smiles>Nc1cc([N+](=O)[O-])ccc1O</smiles>

$$
\mathrm{E}_{1} \neq \mathrm{E}_{2} \neq \mathrm{E}_{3}
$$

Scheme 4. Electrode reaction pathway of azo-derivative (3).

compounds as a result of proton dissociation of the hydroxyl group. The isosbestic point indicated the presence of an acid-base equilibrium between non-ionized and ionized species. The ionic form absorbs at longer wavelength indicating that the interamolecular charge transfer is easier in the ionic form than in the non-ionic one, confirming that the interamolecular charge transfer is influenced by the $\mathrm{OH}$ group. For 4-amino-2-methylquinoline (1), its absorbance spectra was also recorded under the same experimental conditions and was found to exhibit absorption band at $\lambda_{\max } 330 \mathrm{~nm}$ at $\mathrm{pH}$ values lower than 8 , whereas, at higher $\mathrm{pH}$ values, this band was blue shifted to $\lambda_{\max } 300 \mathrm{~nm}$. This behavior may be due to that protonation of species takes place on the nitrogen of quinoline moiety in solutions of $\mathrm{pH}$ lower than 8. However, with the increase of the $\mathrm{pH}$ values of the medium, deprotonation takes place. The changes in the absorption spectra on varying the $\mathrm{pH}$ of solutions were used for determination of the dissociation constant (pKa) of the examined compounds $(\mathbf{1}, \mathbf{2}$ and $\mathbf{3})$. The absorbance-
$\mathrm{pH}$ curves at two different wavelengths were typical $Z$ or $S$-shaped (Figure 5) which indicated the transformation of the molecule from one form into another one.

Values of the dissociation constant ( $\mathrm{pKa}$ ) of the investigated compounds were determined at two different wavelengths (except compound 1) using different methods namely: (i) half-height, (ii) limiting absorbance, (iii) modified limiting absorbance, (iv) isosbestic point and (v) modified isosbestic point. ${ }^{36-38}$ The obtained pKa values are reported in Table 3.

The observed high values of $\mathrm{pKa}$ of the synthesized azo-derivatives ( $\mathbf{2}$ and $\mathbf{3}$ ) may be attributed to the location of the ionizable group $(-\mathrm{OH})$ in an ortho-position where it has lower ability to release $\mathrm{H}^{+}$ion. ${ }^{39,40}$

\section{Potentiometric studies}

The average number of protons associated with the reagent molecule $\overline{\mathrm{n}_{\mathrm{A}}}$ at different $\mathrm{pH}$ values ${ }^{41}$ was calculated 


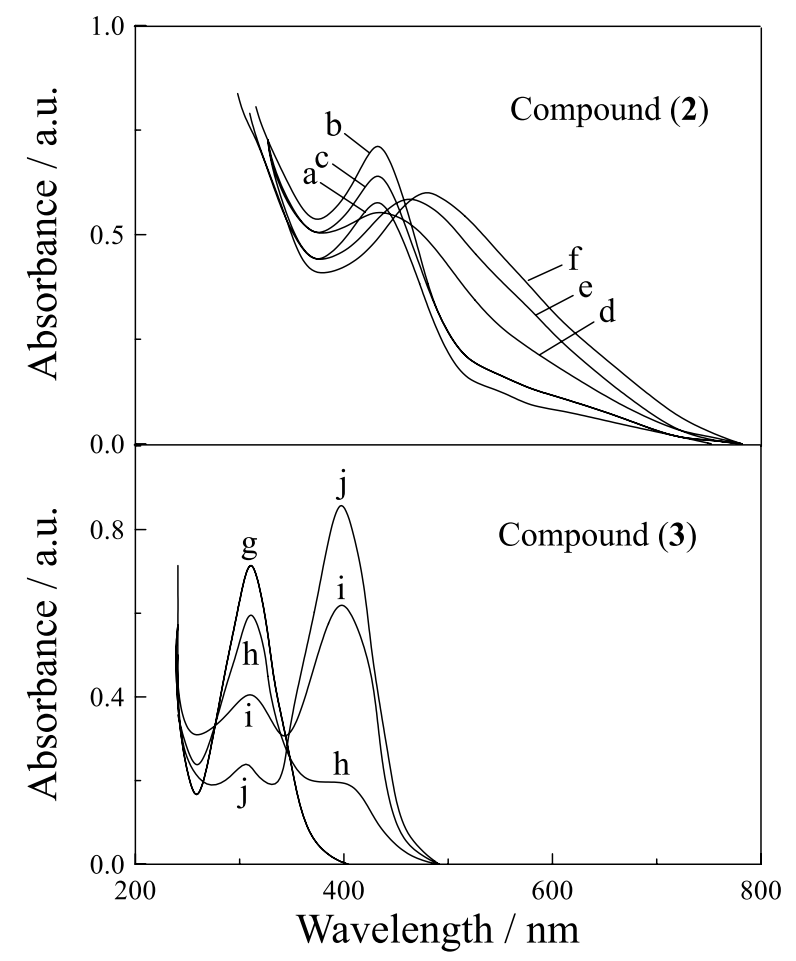

Figure 4. UV-Vis spectra of the examined compounds $\left(5 \times 10^{-4} \mathrm{~mol} \mathrm{~L}^{-1}\right)$ in B-R universal buffer of various $\mathrm{pH}$ values, compound (2): (a) 2, (b) 4, (c) 6, (d) 9, (e) 10 and (f) 11, and compound (3): (g) 3.0, (h) 6.3, (i) 7.3 and (j) 9.2 .

from the titration curves of $\mathrm{HCl}$ solution in the absence and in presence of the examined azo-derivative ( 2 or 3 ) against $0.02 \mathrm{~mol} \mathrm{~L}^{-1} \mathrm{NaOH}$ aqueous-ethanolic solution $(40 \%$ $\mathrm{v} / \mathrm{v}$ ethanol) at $298 \mathrm{~K}$ (Figure 6). Thus, the formation curves $\left(\overline{\mathrm{n}_{\mathrm{A}}} v s . \mathrm{pH}\right)$ for the proton-ligand systems ${ }^{42}$ were constructed and found to extend between 0 and 1.0 in the $\overline{n_{\mathrm{A}}}$ scale for both compounds ( 2 and $\mathbf{3}$ ). This means that each of the examined compounds $\mathbf{2}$ and $\mathbf{3}$ has one dissociable proton from the enolized hydrogen ion of the hydroxyl group (Table 4). This indicates that the acid-base equilibrium based on the molecular form $\mathrm{HL}$ is in complete accordance with the following equilibrium:

$\mathrm{HL} \stackrel{\mathrm{pK}_{1}^{\mathrm{H}}}{\rightleftharpoons} \mathrm{L}^{-}+\mathrm{H}^{+}$

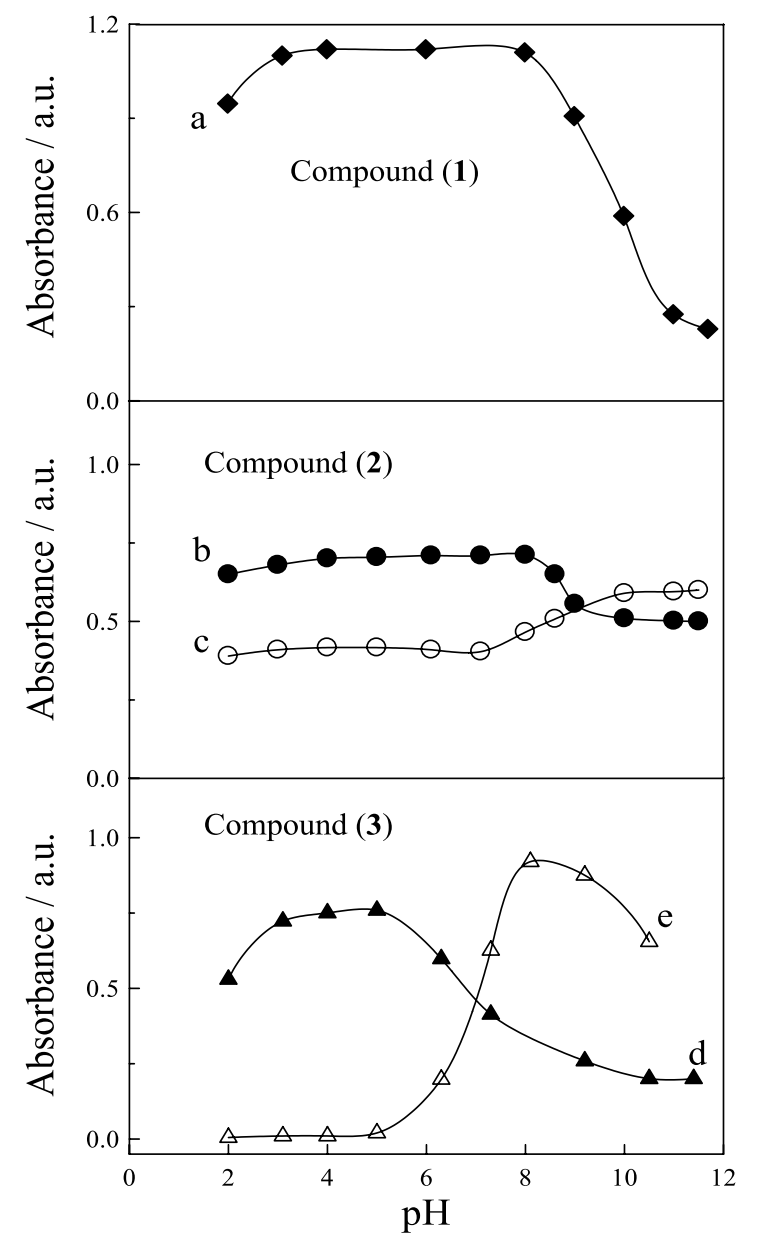

Figure 5. Plots of absorbance $v s$. $\mathrm{pH}$ of the investigated compounds $\left(5 \times 10^{-4} \mathrm{~mol} \mathrm{~L}^{-1}\right)$ in B-R universal buffer of different $\mathrm{pH}$ values, compound (1): $\lambda_{\max }$ at $330 \mathrm{~nm}$ (a), compound (2): $\lambda_{\max }$ at 438 (b) and $480 \mathrm{~nm}$ (c), and compound (3): $\lambda_{\max }$ at 315 (d) and $400 \mathrm{~nm}$ (e).

As shown in Table 4, compound (2) has a lower acidic character $\left(\mathrm{pK}_{1}^{\mathrm{H}}=8.75\right)$ than compound $(3)\left(\mathrm{pK}_{1}^{\mathrm{H}}=7.5\right)$. This is quite reasonable because the presence of $\mathrm{NH}_{2}$ group enhances the electron density by its high electrondonating mesomeric and inductive effects, respectively; thereby stronger $\mathrm{O}-\mathrm{H}$ bond is formed. The presence of electron withdrawing group $\mathrm{NO}_{2}$ leads to the opposite effect, ${ }^{39,40}$ thus the $\mathrm{pK}_{1}^{\mathrm{H}}$ values for the examined compounds follow

Table 3. Dissociation constants (pKa) of the compounds under investigation in ethanolic-aqueous B-R universal buffer using: the half-height ( $i$ ), limitingabsorbance (ii), modified limiting-absorbance (iii), isosbestic point (iv) and modified isosbestic point (v) methods

\begin{tabular}{|c|c|c|c|c|c|c|c|}
\hline \multirow{2}{*}{ Compound } & \multirow{2}{*}{$\begin{array}{c}\lambda_{\max } / \mathrm{nm} \\
\left(\mathrm{n}-\pi^{*}\right)\end{array}$} & \multicolumn{5}{|c|}{ Dissociation constants (pKa) } & \multirow{2}{*}{ Mean value } \\
\hline & & (i) & (ii) & (iii) & (iv) & $(v)$ & \\
\hline 1 & 330 & 9.8 & 10.1 & 9.75 & - & - & 9.88 \\
\hline \multirow[t]{2}{*}{2} & 438 & 9.4 & 11.05 & 9.35 & 9.55 & 8.30 & 9.53 \\
\hline & 480 & 8.6 & 6.35 & 8.40 & & & 7.78 \\
\hline \multirow[t]{2}{*}{3} & 315 & 7.4 & 8.20 & 7.35 & 7.25 & 7.05 & 7.45 \\
\hline & 400 & 6.9 & 6.95 & 7.00 & & & 6.95 \\
\hline
\end{tabular}


Table 4. Stepwise stability constants (ML and $\mathrm{ML}_{2}$ chelates) of the synthesized azo-derivatives ( $\mathbf{2}$ and $\mathbf{3}$ ) in $40 \%$ (v/v) ethanol-water solution containing $1 \mathrm{~mol} \mathrm{~L}^{-1} \mathrm{KCl}$ at $298 \mathrm{~K}$

\begin{tabular}{|c|c|c|c|c|c|c|}
\hline \multirow{2}{*}{$\mathrm{M}^{+\mathrm{n}}$} & \multicolumn{3}{|c|}{ Compound (2) } & \multicolumn{3}{|c|}{ Compound (3) } \\
\hline & $\mathrm{pK}_{1}^{\mathrm{H}}$ & $\log \mathrm{K}_{1}$ & $\log \mathrm{K}_{2}$ & $\mathrm{pK}_{1}^{\mathrm{H}}$ & $\log \mathrm{K}_{1}$ & $\log \mathrm{K}_{2}$ \\
\hline $\mathrm{H}^{+}$ & $8.75 \pm 0.09$ & & & $7.5 \pm 0.1$ & & \\
\hline $\mathrm{Co}^{2+}$ & & $5.87 \pm 0.07$ & $4.02 \pm 0.06$ & & $6.32 \pm 0.06$ & $5.11 \pm 0.08$ \\
\hline $\mathrm{Ni}^{2+}$ & & $6.15 \pm 0.07$ & $4.29 \pm 0.09$ & & $6.95 \pm 0.10$ & $5.83 \pm 0.12$ \\
\hline $\mathrm{Cu}^{2+}$ & & $6.48 \pm 0.06$ & $4.55 \pm 0.08$ & & $8.45 \pm 0.11$ & $6.30 \pm 0.07$ \\
\hline $\mathrm{La}^{3+}$ & & $6.30 \pm 0.10$ & $4.43 \pm 0.09$ & & $7.54 \pm 0.08$ & $6.10 \pm 0.09$ \\
\hline $\mathrm{UO}_{2}^{2+}$ & & $6.62 \pm 0.09$ & $4.75 \pm 0.10$ & & $9.26 \pm 0.08$ & $6.80 \pm 0.10$ \\
\hline
\end{tabular}

Each value is the mean of three readings \pm standard deviation.

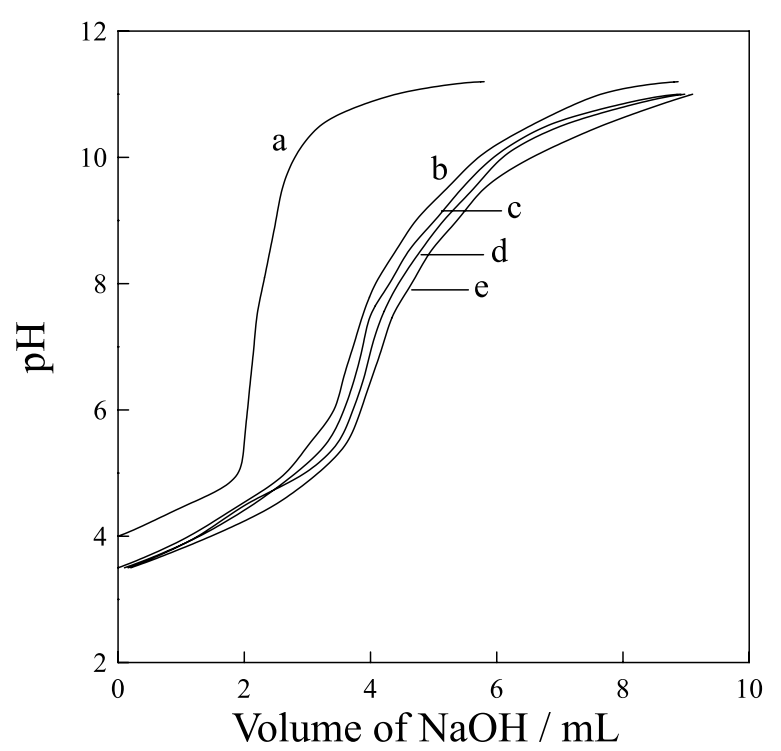

Figure 6. Potentiometric titration curves against $0.02 \mathrm{~mol} \mathrm{~L}^{-1} \mathrm{NaOH}$ ethanolic-queous $40 \%(\mathrm{v} / \mathrm{v})$ solution at $298 \mathrm{~K}$ for the solution mixtures: (a) $5 \mathrm{~mL}$ of $0.01 \mathrm{~mol} \mathrm{~L}^{-1} \mathrm{HCl}+5 \mathrm{~mL}$ of $1 \mathrm{~mol} \mathrm{~L}^{-1} \mathrm{KCl}+20 \mathrm{~mL} \mathrm{EtOH}+$ $20 \mathrm{~mL} \mathrm{H}_{2} \mathrm{O}$, (b) $5 \mathrm{~mL}$ of $0.01 \mathrm{~mol} \mathrm{~L}^{-1} \mathrm{HCl}+5 \mathrm{~mL}$ of $1 \mathrm{~mol} \mathrm{~L}^{-1} \mathrm{KCl}+5 \mathrm{~mL}$ of $5 \times 10^{-3} \mathrm{~mol} \mathrm{~L}^{-1}$ azo-derivative (2) $+15 \mathrm{mLEtOH}+20 \mathrm{~mL} \mathrm{H}_{2} \mathrm{O}$, (c) $5 \mathrm{~mL}$ of $0.01 \mathrm{~mol} \mathrm{~L}^{-1} \mathrm{HCl}+5 \mathrm{~mL}$ of $1 \mathrm{~mol} \mathrm{~L}^{-1} \mathrm{KCl}+5 \mathrm{~mL}$ of $5 \times 10^{-3} \mathrm{~mol} \mathrm{~L}^{-1}$ azo-derivative (2) $+5 \mathrm{~mL}$ of $2 \times 10^{-3} \mathrm{~mol} \mathrm{~L}^{-1} \mathrm{Co}$ (II) $+15 \mathrm{~mL} \mathrm{EtOH}+$ $15 \mathrm{~mL} \mathrm{H}_{2} \mathrm{O}$, (d) the same solution mixture $+2 \times 10^{-3} \mathrm{~mol} \mathrm{~L}^{-1} \mathrm{Ni}$ (II), and (e) the same solution mixture $+2 \times 10^{-3} \mathrm{~mol} \mathrm{~L}^{-1} \mathrm{Cu}$ (II).

the sequence $\mathbf{2}>\mathbf{3}$. The results obtained are of the same order when compared to those spectrophotometrically obtained (Table 3 ).

The average number of reagent molecules attached per metal ion $\bar{n}$, at different $\mathrm{pH}$ values, was calculated from the titration curves of $\mathrm{HCl}$ solutions in the absence and the presence of the examined azo-derivative ( 2 or 3 ) and the selected metal ions ( $\mathrm{Co}(\mathrm{II}), \mathrm{Ni}(\mathrm{II}), \mathrm{Cu}(\mathrm{II}), \mathrm{La}(\mathrm{III})$ or $\mathrm{UO}_{2}^{2+}$ ) against $0.02 \mathrm{~mol} \mathrm{~L}^{-1} \mathrm{NaOH}$ aqueous-ethanolic solution ( $40 \% \mathrm{v} / \mathrm{v}$ ethanol) at $298 \mathrm{~K}$ (Figure 6).

The metal-titration curves (curves c-e) were well separated from that of free ligand (curve b), along the axis of added volume of $\mathrm{NaOH}$ solution, which is attributed to the release of $\mathrm{H}^{+}$ions as a result of the complexation process (Figure 6). The formation curves for the metal complexes of the two azo-derivative ( $\mathbf{2}$ and $\mathbf{3}$ ) with the selected metal ions (Co(II), Ni(II), $\mathrm{Cu}(\mathrm{II}), \mathrm{La}(\mathrm{III})$ or $\mathrm{UO}_{2}^{2+}$ ) were obtained by plotting the average number of ligands attached per metal ion ( $(\overline{\mathrm{n}}) v s$. the free ligand exponent $(\mathrm{pL}){ }^{42}$

By analysis of the formation curves ${ }^{43,44}$ the successive stability constant $\log \mathrm{K}_{1}$ and $\log \mathrm{K}_{2}$ of the studied metal complexes $\mathrm{ML}$ and $\mathrm{ML}_{2}$, respectively, were determined (Table 4) using a constructed QuickBasic language-PC program. As shown in Table 4, the differences observed in the standard deviations (SD) of the obtained data under the same experimental conditions were insignificant, confirming reproducibility and precision of the results. The data obtained can be pointed out based on the following: (i) no precipitate was observed in the titration vessel, indicating that the formation of metal hydroxide is excluded; (ii) the maximum $\overline{\mathrm{n}}$ values for all investigated metal complexes were found to be ca. 2 , revealing that both $\mathrm{ML}$ and $\mathrm{ML}_{2}$ types of complexes are formed in solution; (iii) for all complexes formed $\log \mathrm{K}_{1}$ were always found higher than those of $\log \mathrm{K}_{2}$ (Table 4), because the vacant sites of the metal ions more freely available for binding of a first ligand than for a second one; ${ }^{40,45}(\mathrm{iv})$ the order of stability constants of the metal complexes of the azo-compounds ( 2 and $\mathbf{3}$ ) at $298 \mathrm{~K}$ were found as: $\mathrm{UO}_{2}^{2+}>\mathrm{La}(\mathrm{III})<\mathrm{Cu}(\mathrm{II})>\mathrm{Ni}(\mathrm{II})>\mathrm{Co}(\mathrm{II})$. The sequence of stability of complexes of compounds (2) and (3) with $\mathrm{Cu}(\mathrm{II})>\mathrm{Ni}(\mathrm{II})>\mathrm{Co}$ (II) are in agreement with that reported by Irving and Williams. ${ }^{46,47}$ The $\mathrm{UO}_{2}^{2+}$ has higher stability than those of the other metal complexes. This may be attributed to the bonded oxygen atoms which increase the electrostatic attraction between the metal ion and the coordinated ligands and overcome any steric hindrance offered by the oxygen of the oxygenated cations. ${ }^{40}$

\section{Conclusions}

Two azo-compounds (2-methyl-4-(5-amino-2-hydroxyphenylazo)-quinoline (2) and 2-methyl-4-(2-hydroxy-5- 
nitrophenylazo)-quinoline (3)) derived from 4-amino-2methylquinoline (1) were synthesized and their chemical structures confirmed by various techniques. Their electrode reaction pathways at the DME and HMDE electrodes in buffered solutions of $\mathrm{pH}$ values (2-11.5) were elucidated. The dissociation constants $(\mathrm{pKa})$ of the investigated compounds were determined using spectrophotometric and potentiometric methods. Besides, stability constant and stoichiometry of their metal complexes in solution with some transition metal ions (Co(II), $\mathrm{Ni}(\mathrm{II}), \mathrm{Cu}(\mathrm{II})$, $\mathrm{La}(\mathrm{III})$ and $\mathrm{UO}_{2}^{2+}$ ) were determined potentiometrically. The results indicated the existence of $\mathrm{ML}$ and $\mathrm{ML}_{2}$ types of complexes in solution.

\section{Supplementary Information}

Supplementary data of IR, and MS spectra of the two synthesized azo-compounds (2-methyl4-(5-amino-2-hydroxy-phenylazo)-quinoline (2) and 2-methyl-4-(2-hydroxy-5-nitrophenylazo)-quinoline (3)) (Figures S1-S4) are available free of charge at http://jbcs.sbq.org.br as PDF file.

\section{References}

1. Raposo, M. M; Fonseca, A. C.; Castro, M. R.; Belsley, M.; Cardoso, M. S.; Carvalho, L. M.; Coelho, P. J.; Dyes Pigm. 2011, 91, 62 .

2. LiHong, N.; Cheng, Z.; ZiHui, C.; Zhi, Z.; Zhong, Yu, L.; FuShi, Z.; YingWu, T.; Chin. Sci. Bull. 2009, 54, 1169.

3. Sacarescu, L.; Sacarescu, G.; Simionescu, M.; Hurduc, N.; J. Inorg. Organomet. Polym. 2009, 19, 348.

4. Dixit, B. C.; Patel, H. M.; Desai, D. J.; J. Serb. Chem. Soc. 2007, 72, 119

5. Khosravi, A.; Moradian, S.; Gharanjig, K.; Taromi, F. A.; Iran. Polym. J. 2005, 14, 667.

6. Raposo, M. M.; Castro, M. R.; Fonseca, A. C.; Schellenberg, P.; Belsley, M.; Tetrahedron 2011, 67, 5198.

7. Raposo, M. M.; Castro, M. R.; Belsley, M.; Fonseca, A. C.; Dyes Pigm. 2011, 91, 454.

8. He, T. C.; Wang, C. S.; Pan, X.; Zhang, C. Z.; Lu, G. Y.; Appl. Phys. B: Lasers Opt. 2009, 94, 653.

9. Maruo, Y. Y.; Akaoka, K.; Nakamura, J.; Sens. Actuators, B 2010, 143, 487.

10. El-Safty, S. A.; Adsorption 2009, 15, 227.

11. Sharma, A. K.; Singh, I.; Food Anal. Methods 2009, 2, 221.

12. Sheremetev, S. V.; Kuznetsov, V. V.; J. Anal. Chem. 2007, 62, 319.

13. Li, X.; Wu, Y.; Gu, D.; Gan, F; Dyes Pigm. 2010, 86, 182.

14. Sujamol, M. S.; Athira C. J.; Sindhu,Y.; Mohanan, K; Spectrochim. Acta, Part A 2010, 75, 106.
15. Nejati, K.; Rezvani, Z.; Seyedahmadian, M.; Dyes Pigm. 2009 , 83, 304.

16. Ahn, S. B.; Kim, J. P.; Shim, W. S.; Fibers Polym. 2009, 10, 643.

17. Albayrak, C.; Gümrükçüoglu, I. E.; Odabasoglu, M.; Iskeleli, N. O.; Agar, E.; J. Mol. Struct. 2009, 932, 4354.

18. Byabartta, P.; Russ. J. Coord. Chem. 2009, 35, 687.

19. Ghoneim, M. M.; El-Desoky, H. S.; Amer, S. A.; Rizk, H. F.; Habazy, A. D.; Dyes Pigm. 2008, 77, 493.

20. Chandra, U.; Gilbert, O.; Swamy, B. E. K.; Bodke, Y. D.; Sherigara, B. S.; Int. J. Electrochem. Sci. 2008, 3, 1044.

21. Menek, N.; Karaman, Y.; Dyes Pigm. 2006, 68, 101.

22. Menek, N.; Karaman, Y.; Dyes Pigm. 2005, 67, 9.

23. Menek, N.; Basaran, S.; Turgut, G.; Odabasoglu, M.; Dyes Pigm. 2004, 61, 85.

24. La-Scalea, M. A.; Serrano, S. H. P.; Gutz, I. G. R.; J. Braz. Chem. Soc. 1999, 10, 127.

25. Goyal, R. N.; Verma, M. S.; Singhal, N. K.; Croat. Chem. Acta 1998, 71, 715 .

26. Moharram, Y. I.; El-Hallag, I. S.; El-Attar, M. A.; Ghoneim, M. M.; Bull. Electrochem. 2005, 21, 297.

27. Vogel, A. I.; A Text Book of Practical Organic Chemistry, $3^{\text {rd }}$ ed.; Longman Publishers: New York, 1961.

28. Meites, L.; Polarographic Techniques, $2^{\text {nd }}$ ed.; Interscience Publishers: New York, 1965, p. 232-248.

29. Zuman, P.; The Elucidation of organic Electrode Process; Academic Press: New York, 1969. p. 22-24.

30 Greef, R.; Peat, R.; Peter, L. M.; Pletcher, D.; Robinson, J.; Instrumental Methods in Electrochemistry, Southampton Electrochemistry Group; Ellis Horwood Limited, John Wiley \& Sons: New York, 1985, p. 187.

31. Ghoneim, M. M.; Ashy, M. A. A.; Can. J. Chem. 1979, 57, 1249.

32. Galus, Z.; Fundamentals of Electrochemical Analysis; John Wiley: New York, 1976, p. 238.

33. Pavia, D. L.; Lampman, G. M.; Kriz, G. S.; Engel, R. G.; Introduction to Organic Laboratory Techniques - SmallScale Approach, $1^{\text {st }}$ ed.; Harcourt Brace: Florida, 1998, p. 313-322.

34. Stradyn, Y. P.; Kadysh, V. P.; Giller, S. A. I.; Khim. Geterotsikl. Soedin. 1973, 12, 1587.

35. Zuman, P.; Microchem. J. 1997, 57, 4-51.

36. Issa, R. M.; El-Ezaby, M. S.; Zewail, A. H.; Z. Phys. Chem. (Leipzig) 1970, 244, 155.

37. Issa, I. M.; Issa, R. M.; El-Ezabey, M. S.; Ahmed, Y. Z.; Z. Phys. Chem. (Leipzig) 1969, 242, 169.

38. Abdelhal, F. M.; Issa, R. M.; El-Ezabey, M. S.; Hasanein, A. A.; Z. Phys. Chem. (Frankfurt) 1970, 73, 59.

39. McMurry, J.; Organic Chemistry, $5^{\text {th }}$ ed.; Brooks/Cole: USA, 2000.

40. Shehatta, I.; Kenawy, I.; Askalany, A. H.; Hassan, A. A.; Can. J. Chem. 2001, 79, 42. 
41. Fronaeus, S.; Complex System of Copper; Gleer Upska Universitets-Bokhandeln: Lund, 1948.

42. Irving, H. M.; Rossotti H. S.; J. Chem. Soc. 1954, 76, 2904.

43. Rossotti, F. J. C.; Rossotti, H. S.; Acta Chem. Scand. 1955, 9 , 1166.

44. Beck, M. T.; Nagybal, I.; Chemistry of Complex Equilibria; Wiley: New York, 1990.
45. Ghoneim, M. M.; El-Hallag, I. S.; El-Baradie, K. Y.; El-Desoky, H. S.; El-Attar, M. A.; Monatsh. Chem. 2006, 137, 285.

46. Irving, H. M.; Williams, R. J. P.; Nature 1948,162, 746.

47. Irving, H. M.; Williams, R. J. P.; Analyst 1952, 77, 813.

Submitted: April 3, 2012

Published online: July 31, 2012 